\title{
EuroSCORE II and STS as mortality predictors in patients undergoing TAVI
}

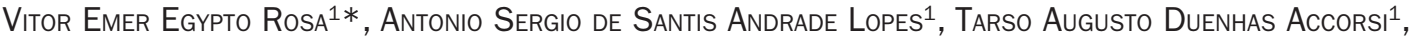 \\ João Ricardo Cordeiro Fernandes ${ }^{1}$, Guilherme Sobreira Spina ${ }^{2}$, Roney Orismar Sampaio ${ }^{2}$, Milena Ribeiro Paixão ${ }^{1}$, \\ Pablo Maria Pomerantzeff ${ }^{3}$, Pedro Alves Lemos Neto ${ }^{4}$, Flávio Tarasoutchi ${ }^{3}$

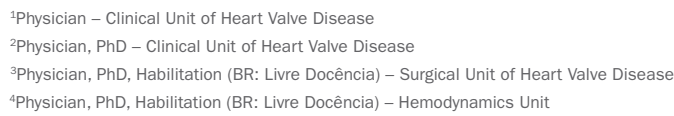

\section{SUMmARY}

Introduction: the EuroSCORE II and STS are the most used scores for surgical risk stratification and indication of transcatheter aortic valve implantation (TAVI). However, its role as a tool for mortality prediction in patients undergoing TAVI is still unclear.

Objective: to evaluate the performance of the EuroSCORE II and STS as predictors of in-hospital and 30-day mortality in patients undergoing TAVI.

Methods: we included 59 symptomatic patients with severe aortic stenosis that underwent TAVI between 2010 and 2014. The variables were analyzed using Student's t-test and Fisher's exact test and the discriminative power was evaluated using receiver operating characteristic curve (ROC) and area under the curve (AUC) with a $95 \%$ confidence interval.

Results: mean age was $81 \pm 7.3$ years, $42.3 \%$ men. The mean EuroSCORE II was $7.6 \pm 7.3 \%$ and STS was $20.7 \pm 10.3 \%$. Transfemoral procedure was performed in $88.13 \%$, transapical in $3.38 \%$ and transaortic in $8.47 \%$. In-hospital mortality was $10.1 \%$ and 30 -day mortality was $13.5 \%$. Patients who died had EuroSCORE II and STS higher than the survivors ( $33.7 \pm 16.7$ vs. $18.6 \pm 7.3 \% \mathrm{p}=0,0001$ for STS and $13.9 \pm 16.1$ vs. $4.8 \pm 3.8 \% \mathrm{p}=0.0007$ for EuroSCORE II). The STS showed an AUC of 0.81 and the EuroSCORE II of 0.77 and there were no differences in the discrimination ability using ROC curves $(\mathrm{p}=0.72$ ).

Conclusion: in this cohort, the STS and EuroSCORE II were predictors of inhospital and 30-days mortality in patients with severe aortic stenosis undergoing TAVI.

Keywords: aortic valve stenosis, prosthetic heart valves, hemodynamics.

\section{INTRODUCTION}

In the last few years, with the advent of transcatheter aortic valve implantation (TAVI), patients with symptomatic severe aortic stenosis, who previously had no treatment possibility due to contraindication or high surgical risk, began to have a treatment option. ${ }^{1}$ Despite this new mode of intervention, these patients have high mortality at 2 years: $33.9 \%$ in high-risk cases and $43.3 \%$ in the inoperable. ${ }^{2,3}$

The Society of Thoracic Surgeons (STS $)^{4,5}$ score and the European System for Cardiac Operative Risk Evalu- ation II (EuroSCORE II) ${ }^{6}$ are used to help stratify surgical risk and the indication of TAVI. However, they have limitations due to the difficulty in differentiating highrisk patients from those in which the procedure can be considered unproductive, and also because they do not include numerous comorbidities that cause adverse surgical outcomes such as chronic obstructive pulmonary disease, liver cirrhosis, pulmonary hypertension, previous cardiac surgery, porcelain aorta, recurrent pulmonary embolism, right ventricular failure, contraindica- 
tion to open chest surgery (previous chest irradiation) or fragility. Thus, the role of risk scores as a predictive tool is questionable and there are no values to define patients not eligible for TAVI. ${ }^{7-9}$

The objective of this study was to evaluate the performance of the EuroSCORE II and STS as predictors of in-hospital mortality and 30-day mortality in patients undergoing TAVI.

\section{Methods}

Single-center retrospective study that included 59 consecutive patients with severe aortic stenosis, defined in accordance with current guidelines, ${ }^{10}$ symptomatic, who underwent TAVI in the period between 2010 and 2014 All cases were evaluated by a multidisciplinary team (Heart team) and underwent clinical assessment, electrocardiogram, chest X-ray, echocardiogram, multislice computed tomography of the aorta and branches, cine coronary angiography and laboratory tests. EuroSCORE II and STS scores were calculated using online tools (www.euroscore.org and riskcalc.sts.org/STSWebRiskCalc273). The procedure was performed in the cardiac catheterization lab or hybrid operating room under general anesthesia and with transesophageal echocardiography guidance. Medtronic CoreValve and Edwards Sapien heart valves were used. Complications and outcomes were defined according to the Valve Academic Research Consortium Consensus on Event Definition. ${ }^{11}$ Fragility, characterized as poor physiological reserve, ${ }^{13}$ was defined based on the index by Fried et al. ${ }^{13}$ derived from the cohort of the Cardiovascular Health Study (CHS) with 5317 patients over 65 years, and includes items such as: weight loss, exhaustion, weakness, walking speed and reduced physical activity. Those with 3 or more criteria are considered fragile, adding risk of post-surgical complications, including mortality. ${ }^{13}$

Continuous variables are presented as means \pm standard error while categorical variables are shown as frequencies and percentages. The continuous variables were analyzed using unpaired Student's t-test, and the categorical variables using Fisher's exact test. Data normality was tested by Kolmogorov-Smirnov test. Discriminative power was assessed by receiver operating characteristic (ROC) curve and area under the curve (AUC), accompanied by $95 \%$ confidence interval. The test used for comparison of ROC curves was DeLong et al. ${ }^{14} \mathrm{~A} p$ value $<0.05$ was considered statistically significant and the software used for the statistical analysis was MedCalc 15.4 (MedCalc Software bvba, Spain). This study was approved by the Research Ethics Committee.

\section{Results}

Population characteristics

Baseline characteristics are described in Table 1. The average age was $81.0 \pm 7.3$ years, $42.3 \%$ men. Etiology was degenerative in $96.61 \%$, rheumatic in $1.69 \%$ and in $1.69 \%$, bicuspid. The valve-in-valve procedure was performed in $8.47 \%$. The average EuroSCORE II was $6.7 \pm 7.3 \%$ and STS $20.7 \pm 10.3 \%$; $13.55 \%$ of patients had EuroSCORE II greater than $10 \%$, while $91.5 \%$ had STS greater than $10 \%$. The electrocardiographic evaluation shows atrioventricular conduction disorders in $15.2 \%$, right bundle branch block in $6.7 \%$ and left bundle branch block in $6.7 \%$. Echocardiography revealed a mean ejection fraction of $56 \pm 13.6 \%$, mean aortic gradient of $47.5 \pm 16.7 \mathrm{mmHg}$ and aortic valve area of $0.69 \pm 0.21 \mathrm{~cm}^{2}$. Regarding laboratory tests, mean hemoglobin was $11.6 \pm 1.8 \mathrm{~g} / \mathrm{dL}$, serum creatinine $1.30 \pm 0.71$ $\mathrm{mg} / \mathrm{dL}$ and urea $60 \pm 29.2 \mathrm{mg} / \mathrm{d}$. The average diameter of the valve annulus measured by computed tomography was $25.4 \pm 3.6$ vs. $24.0 \pm 4.7 \mathrm{~mm}$ and the distances of the left and right coronary ostia were $13.4 \pm 2.6 \mathrm{~mm}$ and $14.1 \pm 3.1$ $\mathrm{mm}$, respectively.

TABLE 1 Baseline characteristics of the population.

\begin{tabular}{ll} 
Characteristics & $\mathbf{n}=\mathbf{5 9}$ \\
\hline Age, years & $81 \pm 7.3$ \\
\hline Male & $25(42.3 \%)$ \\
\hline Etiology & \\
\hline Degenerative & $57(96.61 \%)$ \\
\hline Rheumatic & $1(1.69 \%)$ \\
\hline Bicuspid & $1(1.69 \%)$ \\
\hline Dysfunction of aortic prosthesis & $5(8.47 \%)$ \\
\hline Diabetes & $17(28.8 \%)$ \\
\hline High blood pressure & $38(64.4 \%)$ \\
\hline Atrial fibrillation & $9(15.2 \%)$ \\
\hline COPD & $4(6.7 \%)$ \\
\hline Coronary artery disease & $20(47.4 \%)$ \\
\hline Heart failure (NYHA) & $52(88.1 \%)$ \\
\hline II & $12(23 \%)$ \\
\hline III & $28(53.8 \%)$ \\
\hline IV & $12(23 \%)$ \\
\hline Chest pain (CCS) & $14(23.7 \%)$ \\
\hline 3 or 4 & $9(64.2 \%)$ \\
\hline Syncope & $10(16.9 \%)$ \\
\hline Right-sided heart failure & $3(5 \%)$ \\
\hline Kidney failure & $28(47.4 \%)$ \\
\hline GFR 30-60 mL/min & $21(75 \%)$ \\
\hline GFR 15-30 mL/min & $5(17.8 \%)$ \\
\hline
\end{tabular}


TABLE 1 (Cont.) Baseline characteristics of the population.

Characteristics

EuroScore II $>10 \%$

$\mathrm{n}=\mathbf{5 9}$

STS score $>10 \%$

$8(13.5 \%)$

Porcelain aorta

$54(91.5 \%)$

$3(5 \%)$

Inoperable

13 ( $22 \%)$

Fragility

$31(52.5 \%)$

Lung cancer

$1(1.6 \%)$

Rheumatoid arthritis (arthritis deformans)

Chronic lymphocytic leukemia

$1(1.6 \%)$

Multiple cardiac surgeries (3)

$1(1.6 \%)$

Myelodysplasia

$1(1.6 \%)$

Radiotherapy

$1(1.6 \%)$

Liver cirrhosis

$1(1.6 \%)$

COPD: chronic obstructive pulmonary disease; GFR. glomerular filtration rate.

\section{Procedure}

Transfemoral access was used in $88.13 \%$, transapical in $3.38 \%$, and transaortic in $8.47 \%$. In $25.42 \%$ of cases, predilatation was required, while $38.9 \%$ underwent post-dilatation due to peri-prosthetic failure. In $11.8 \%$, coronary angioplasty was performed before the procedure. Medtronic CoreValve heart valves were used in $64.4 \%$ of patients, and Edwards Sapien valves in 35.59\%.

\section{Outcomes}

General in-hospital mortality was $10.1 \%$ and 30 -day mortality was $13.5 \%$, all related to the procedure (Table 2 ). Two deaths (3.38\%) occurred during the procedure due to cardiac tamponade. The remainder was caused by poor positioning of the prosthesis/thrombosis (1.69\%), sepsis with worsening of heart function (3.38\%), infective endocarditis with coronary embolization (1.69\%) and aortic rupture (1.69\%). None of the other deaths were witnessed. As for the transfemoral procedure alone, in-hospital mortality was $5.08 \%$ and 30 -day mortality was $8.47 \%$. In-hospital outcomes included stroke in $5.08 \%$, major vascular complications in $8.47 \%$, myocardial infarction in $1.69 \%$, infective endocarditis in 5.08\%, kidney injury in $23.7 \%$, and need for permanent pacemaker implantation in $8.47 \%$. In the latter, $10.8 \%$ used Medtronic CoreValve heart valves and $4.5 \%$ used Edwards Sapien valves.

\section{Predictors}

In the overall analysis, patients who died showed STS and EuroSCORE II significantly higher than the survivors $(33.7 \pm 16.7$ vs. $18.6 \pm 7.3 \%$; $\mathrm{p}=0.0001$ for STS and $13.9 \pm 16.1$ vs. $4.8 \pm 3.8 \%$; $=0.0007$ for EuroSCORE II). In
TABLE 2 Outcomes.

\begin{tabular}{ll} 
& $\mathbf{n}=\mathbf{5 9}$ \\
\hline In-hospital mortality & $\mathbf{6 ( 1 0 . 1 \% )}$ \\
\hline 30-day mortality & $\mathbf{8 ( 1 3 . 5 \% )}$ \\
\hline Causes of death & $2(3.38 \%)$ \\
\hline Cardiac Tamponade & $1(1.69 \%)$ \\
\hline Poor positioning of the prosthesis/thrombosis & $2(3.38 \%)$ \\
\hline Sepsis with worsening of heart function & $1(1.69 \%)$ \\
\hline Infective endocarditis & $1(1.69 \%)$ \\
\hline Aortic rupture & $3(5.08 \%)$ \\
\hline Death not witnessed & \\
\hline Other & $3(5.08 \%)$ \\
\hline Stroke & $5(8.47 \%)$ \\
\hline Major vascular complications & $1(1.69 \%)$ \\
\hline Myocardial infarction & $3(5.08 \%)$ \\
\hline Infective endocarditis & $14(23.7 \%)$ \\
\hline Kidney injury & $5(8.47 \%)$ \\
\hline Permanent pacemaker implantation & \\
\hline
\end{tabular}

the ROC curve analysis, STS showed AUC at 0.81, while EuroSCORE II AUC was 0.77; no difference was found in discrimination ability using ROC $(\mathrm{p}=0.72)$ (Figure 1). Other clinical, laboratory and echocardiographic variables, as well as those related to the procedure, were analyzed and did not show statistical significance, except for left ventricular ejection fraction, higher in the patients who died $(\mathrm{p}=0.03)$ (Table 3$)$.

TABLE 3 Variables related to supplementary exams.

\begin{tabular}{|c|c|c|c|}
\hline & $\begin{array}{l}\text { Survival } \\
(n=51)\end{array}$ & Death $(n=8)$ & $\mathbf{p}$ \\
\hline AV disease, $\mathrm{n}$ & 1 & 1 & 0.25 \\
\hline $\begin{array}{l}\text { Right bundle branch } \\
\text { block, } n\end{array}$ & 3 & 1 & 0.45 \\
\hline $\begin{array}{l}\text { Left bundle branch } \\
\text { block, } \mathrm{n}\end{array}$ & 4 & 0 & 1.00 \\
\hline Ejection fraction, \% & $54.58 \pm 14.18$ & $65.25 \pm 1.71$ & 0.03 \\
\hline LV-Ao gradient, $\mathrm{mmHg}$ & $46.68 \pm 16.02$ & $53.0 \pm 19.63$ & 0.31 \\
\hline Aortic valve area, $\mathrm{cm}^{2}$ & $0.70 \pm 0.22$ & $0.63 \pm 0.12$ & 0.38 \\
\hline Hemoglobin, g/dL & $11.7 \pm 1.86$ & $11.46 \pm 1.46$ & 0.72 \\
\hline Creatinine, $\mathrm{mg} / \mathrm{dL}$ & $1.29 \pm 0.75$ & $1.35 \pm 0.36$ & 0.82 \\
\hline Urea, $\mathrm{mg} / \mathrm{dL}$ & $59.46 \pm 30.26$ & $63.75 \pm 21.6$ & 0.70 \\
\hline $\begin{array}{l}\text { Left coronary artery } \\
\text { Height, } \mathrm{cm}\end{array}$ & $13.33 \pm 2.43$ & $14.12 \pm 3.62$ & 0.42 \\
\hline $\begin{array}{l}\text { Right coronary artery } \\
\text { Height, } \mathrm{cm}\end{array}$ & $14.00 \pm 3.14$ & $15.02 \pm 3.06$ & 0.39 \\
\hline
\end{tabular}




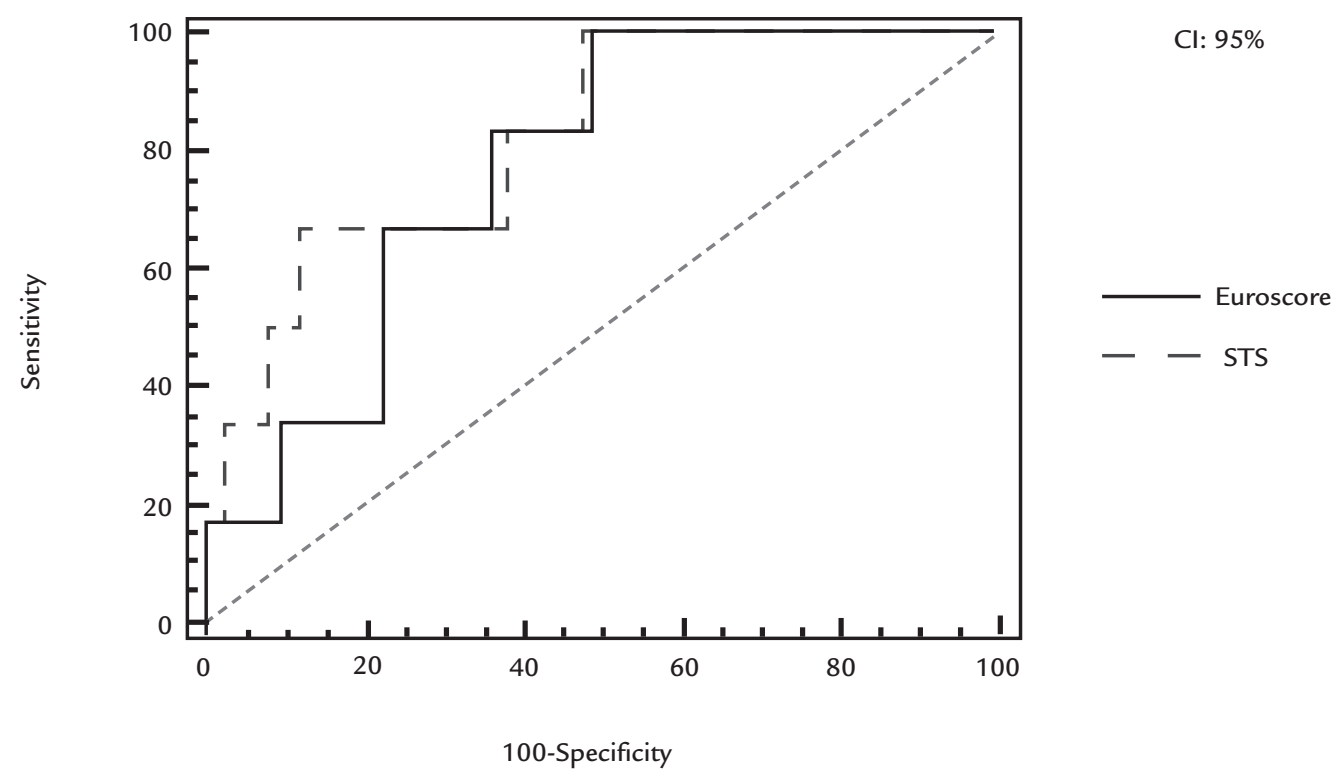

FIGURE 1 ROC curve analysis: STS showed AUC at 0.81, while EuroSCORE II AUC was 0.77.

Among the patients undergoing transfemoral procedure, STS and EuroSCORE II results of those who died were higher than observed in the surviving group (38.1 \pm 18.1 vs. $18.7 \pm 7.5 \%$; $<<0.01$ for STS and $18.6 \pm 17.4$ vs. $4.9 \pm 3.9 \%$; $<0.01$ for EuroSCORE II).

In the global univariate analysis, right bundle branch block was a predictor of permanent pacemaker (OR 24.0, $R R$ 12.5; $p=0,024)$. There was no association between type of cardiac prosthesis and need for pacemaker $(p=0.641)$.

\section{Discussion}

The risk scores currently used (EuroSCORE II \& STS) were derived from databases of patients undergoing cardiac surgery. ${ }^{15,16}$ In addition, TAVI patients are usually elderly, with greater surgical risk and with numerous risk factors often not included in the current scores. ${ }^{7-9,15,16}$ For these reasons, there is a need to identify predictors that help distinguish patients who may not benefit from the percutaneous procedure.

Data reported in the literature differ with respect to the mortality prediction ability of the EuroSCORE II and STS scores. While Stahli et al. ${ }^{16}$ in a cohort of 350 patients and Sedaghat et al. ${ }^{15}$ in a cohort of 206 patients demonstrated the superiority of EuroSCORE II, Hemmann et al. ${ }^{17}$ in a record of 426 patients considered the STS superior. Other studies, as well as our work, demonstrated no difference between the scores, and, in our case, both the EuroSCORE II and STS scores had the ability to predict mortality, with AUC of 0.77 and 0.81, respectively. Since in our population the number of transaortic and transapical procedures was significantly lower than that of transfemoral procedures, preventing a comparative analysis, we chose to analyze the transfemoral procedure separately, and the findings were similar to the global analysis regarding mortality predictors.

In our study, STS overestimated the in-hospital and 30-day mortality rates, while the EuroSCORE II underestimated this outcome (Figure 2). One possible explanation for this finding is the fact that the STS score is composed of 40 clinical parameters for calculation, while the EuroSCORE II requires only 18. Despite that, in our study, STS score did not prove to be better able to predict mortality. ${ }^{16}$

A finding in this study was that the left ventricular ejection fraction of patients who progressed to death was significantly higher than seen in the survivors $(65.25 \pm 1.74 \%$ for death and $54.58 \pm 14.18$ for survival; $\mathrm{p}=0.03$ ). However, the average of the two groups was within the normal range and none of the witnessed deaths was due to cardiogenic shock.

Among the risk variables not included in the scores, fragility is a challenge for preoperative evaluation and causes significant impact on morbidity and postoperative mortality. ${ }^{12,13}$ It was observed in $52.5 \%$ of patients and in $75 \%$ of those who died, confirming its importance for indication of percutaneous procedure and its influence 


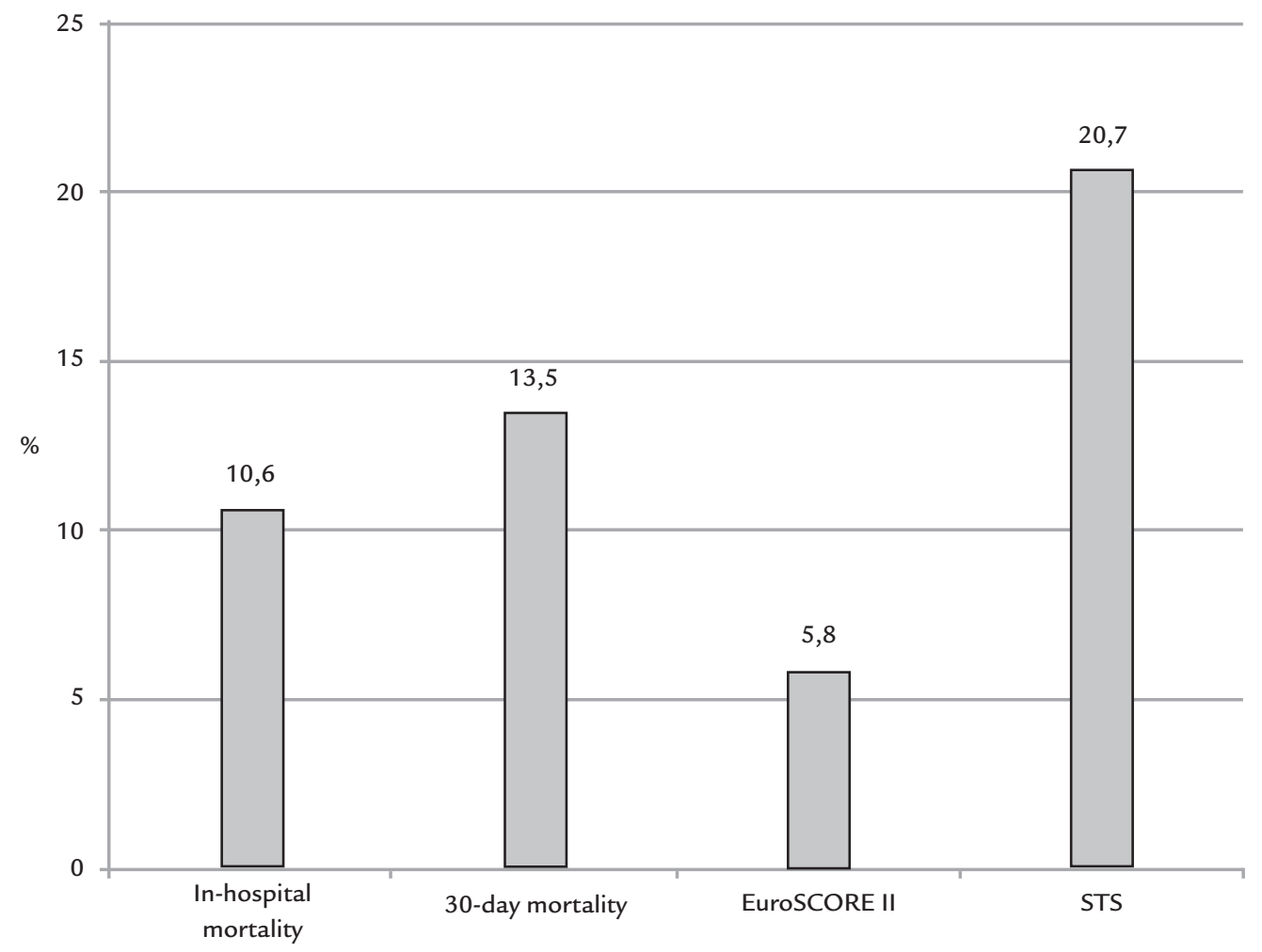

FIGURE 2 Mortality observed in hospital, in 30 days, and predicted by EuroSCORE II and STS scores.

on mortality in this therapeutic modality, although without statistical significance.

\section{LiMitATIONS}

This is a single-center study with a small sample population. In addition, being a record, it has no power to assess the impact of prognostic tools.

\section{Conclusion}

In this cohort, among patients with severe aortic stenosis undergoing TAVI, STS and EuroSCORE II were predictors of in-hospital and 30-day mortality. In the absence of a risk score developed exclusively for this procedure, these scores can be useful as tools to aid clinical decision.

\section{Resumo}

EuroSCORE II e STS como preditores de mortalidade em pacientes submetidos ao TAVI

Introdução: STS e EuroSCORE II são os escores mais utilizados para a estratificação de risco cirúrgico e indicação do implante de válvula aórtica transcateter (TAVI).
Entretanto, seu papel como ferramenta para predição de mortalidade em pacientes submetidos ao TAVI ainda é incerto.

Objetivo: avaliar o desempenho do EuroSCORE II e STS como preditores de mortalidade intra-hospitalar em 30 dias em pacientes submetidos ao TAVI.

Métodos: 59 pacientes com estenose aórtica importante submetidos ao TAVI entre 2010 e 2014 . Variáveis foram analisadas por meio do teste t-Student e teste exato de Fisher, e o poder discriminativo foi avaliado pela curva ROC e área sob a curva, acompanhada de intervalo de confiança de $95 \%$.

Resultados: a idade média foi de $81 \pm 7,3$ anos, $42,3 \%$ ho-

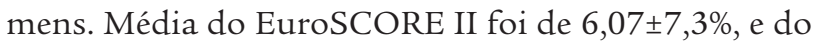
STS, $20,7 \pm 10,3 \%$. Procedimento transfemoral foi realizado em $88,13 \%$, transapical, em 3,38\% e transaórtico, em $8,47 \%$. A mortalidade intra-hospitalar foi $10,1 \%$, e em 30 dias, $13,5 \%$. Os pacientes que evoluíram para óbito apresentavam STS e EuroSCORE II mais elevados que os sobreviventes $(33,7 \pm 16,7 \%$ vs. $18,6 \pm 7,3 \%$; $\mathrm{p}=0,0001$ para STS e $13,9 \pm 16,1 \%$ vs. $4,8 \pm 3,8 \%$; $\mathrm{p}=0,0007$ para EuroSCORE II). O STS apresentou AUC de 0,81, e o EuroSCORE II, 0,77. Não houve diferença na capacidade de discriminação pelas curvas $\operatorname{ROC}(\mathrm{p}=0,72)$. 
Conclusão: STS e EuroSCORE II foram preditores de mortalidade intra-hospitalar em 30 dias.

Palavras-chave: estenose da valva aórtica, próteses valvulares cardíacas, hemodinâmica.

\section{References}

1. Brito Jr FS, Abizaid A, Almeida BO, Caixeta A, Tarasoutchi F, Grube E, et al. Implante por cateter de bioprótese valvar para tratamento da estenose aórtica: experiência de três anos. Arq Bras Cardiol. 2012; 99(2):697-705.

2. Kodali SK, Williams MR, Smith CR, Svensson LG, Webb JG, Makkar RR, et al. Two-year outcomes after transcatheter or surgical aortic-valve replacement. N Engl J Med. 2012; 366:1686-95.

3. Leon MB, Smith CR, Mack M, Miller DC, Moses JW, Svensson LG, et al Transcatheter aortic-valve implantation for aortic stenosis in patients who can not undergo surgery. N Engl J Med. 2010; 363:1597-607.

4. O'Brien SM, Shahian DM, Filardo G, Ferraris VA, Haan CK, Rich JB, et al. The Society of Thoracic Surgeons 2008 cardiac surgery risk models: part 2 isolated valve surgery. Ann Thorac Surg. 2009; 88:S23.

5. Shahian DM, O'Brien SM, Filardo G, Ferraris VA, Haan CK, Rich JB, et al. The Society of Thoracic Surgeons 2008 cardiac surgery risk models: part 1coronary artery bypass grafting surgery. Ann Thorac Surg. 2009; 88:S2

6. Nashef SA, Roques F, Sharples LD, Nilsson J, Smith C, Goldstone AR, et al EuroSCORE II. Eur J Cardiothorac Surg. 2012; 41:734.

7. Mylotte D, Martucci G, Piazza N. Patient selection for transcatheter aortic valve implantation: An interventional cardiology perspective. Ann Cardiothorac Surg. 2012; 1(2):206-15

8. Van Mieghem NM, Serruys PW. The art of risk stratification in TAVI. Eur Heart J. 2013; 34:1859-61.
9. Durand E, Borz B, Godin M, Tron C, Litzler PY, Bessou JP, et al. Performance analysis of EuroSCORE II compared to the original logistic EuroSCORE and STS scores for predicting 30-day mortality after transcatheter aortic valve replacement. Am J Cardiol. 2013; 111(6):891-7.

10. Tarasoutchi F, Montera MW, Grinberg M, Barbosa MR, Piñeiro DJ, Sánchez CRM, et al. Diretriz Brasileira de Valvopatias - SBC 2011 / I Diretriz Interamericana de Valvopatias - SIAC 2011. Arq Bras Cardiol. 2011; 97(5 supl. 1):1-67.

11. Kappetein AP, Head SJ, Généreux P, Piazza N, van Mieghem NM, Blackstone $\mathrm{EH}$, et al. Updated standardized endpoint definitions for transcatheter aortic valve implantation: the Valve Academic Research Consortium- 2 consensus document. J Am Coll Cardiol. 2012; 60:1438e1454.

12. Ahmed N, Mandel R, Fain MJ. Frailty: an emerging geriatric syndrome. Am J Med. 2007; 120:748-53.

13. Fried LP, Tangen CM, Walston J, Newman AB, Hirsch C, Gottdiener J, et al. Frailty in older adults: evidence for a phenotype. J Gerontol A Biol Sci Med Sci. 2001; 56:M146-56.

14. DeLong ER, DeLong DM, Clarke-Pearson DL. Comparing the areas under two or more correlated receiver operation characteristic curves: a nonparametric approach. Biometrics. 1988; 44(3):837-45.

15. Sedaghat A, Sinning JM, Vasa-Nicotera M, Ghanem A, Hammerstingl C, Grube E, et al. The revised EuroSCORE II for the prediction of mortality in patients undergoing transcatheter aortic valve implantation. Clin Res Cardiol. 2013; 102(11):821-9.

16. Stähli BE, Tasnady H, Lüscher TF, Gebhard C, Mikulicic F, Erhart L, et al. Early and late mortality in patients undergoing transcatheter aortic valve implantation: comparison of the novel EuroScore II with established risk scores. Cardiology. 2013; 126(1):15-23.

17. Hemmann K, Sirotina M, De Rosa S, Ehrlich JR, Fox H, Weber J, Moritz A et al. The STS score is the strongest predictor of long-term survival following transcatheter aortic valve implantation, whereas access route (transapical versus transfemoral) has no predictive value beyond the periprocedural phase. Interact Cardiovasc Thorac Surg. 2013; 17(2):359-64. 